Article

\title{
Responsible Decision making for Sustainable Motivation
}

\author{
Martina Blašková ${ }^{1, *}$, Irena Figurska ${ }^{2}$, Ruta Adamoniene ${ }^{3}$, Kristína Poláčková ${ }^{1}$ and \\ Rudolf Blaško ${ }^{4}$ \\ 1 Department of Managerial Theories, University of Žilina, 01026 Žilina, Slovakia; \\ kristina.trskova@gmail.com \\ 2 Department of Social Work, Pomeranian University, 76-200 Słupsk, Poland; irenafigurska@vp.pl \\ 3 Department of Humanities, Mykolas Romeris University, LT-44211 Kaunas, Lithuania; rutadam@mruni.eu \\ 4 Department of Mathematical Methods and Operational Analysis, University of Žilina, 01026 Žilina, Slovakia; \\ beerb@frcatel.fri.uniza.sk \\ * Correspondence: blaskova.fri@gmail.com or blaskova@fri.uniza.sk; Tel.: +421-41-5134455
}

Received: 18 July 2018; Accepted: 7 September 2018; Published: 23 September 2018

\begin{abstract}
This article examines motivation and the quality of decision making's effect on motivation as important preconditions for organizational sustainability. The article is focused on an examination of the content and intensity of perceived motivation, and the forms of decisions that were made while motivating people. Motivation (from a theoretical and empirical point of view) is related to crucial processes of human potential development and motivation. The analysis, synthesis and generalization of knowledge related to sustainability, motivation and decision making in human potential motivation are presented in the theoretical part of the article. The empirical part presents the results of sociological questionnaire, focusing on the area of decision making in motivation that was carried out on sample of respondents in the Slovak Republic $(n=500)$, Poland $(n=390)$ and Lithuania $(n=226)$. The results confirm a strong correlation between the level of the motivation and the quality of key processes of development of human potential (leadership, appraisal, communication, and the creation of an atmosphere of trust). In all examined countries and processes, the calculated values of the chi-square test were significantly higher than the table value (level of significance $=0.05$ ). The section describing the results contains a proposed content-componential model of decision making in affecting and building sustainable motivation.
\end{abstract}

Keywords: sustainability; motivation; decision making; human potential; motivation programs

\section{Introduction}

One of mankind's greatest challenges this century will be to ensure sustainable, fair and balanced development [1]. Sustainability currently can be defined as a necessary thought-action approach in the progression of all organizational processes while retaining the dynamics, acceleration, and value-creating balance between the present and future, with a significant impact on societal contribution. According to the World Commission on Environment and Development, building a commitment to sustainability among citizens is largely a matter of educating them so they can recognize the scientific facts of environmental damage and subsequently act in an appropriate way [2].

Sustainability typically has been viewed from three perspectives: environmental, economic, and social [3,4], although there are many others. Recently, perspectives on sustainability have been adjusted for different fields of its application, such as in regard to the environmental or green aspects of business [5], corporate social responsibility [6,7], social and cultural conditions [8], responsible research and innovation [9,10], economic progress [11], public health, community and knowledge capacities [12], 
synergetic effects $[13,14]$, and more. According to Tovey, “ ... when speaking of 'sustainability' we may also have other goals in mind: perhaps what we want to sustain is society ... " [15].

Aligned with adjusting the scope and application of sustainability and its societal perspective, all created values, ideas, and solutions (both present and future ones) are the results of the deliberate effort of human beings and their thoughts. Based on this idea, this article presumes that motivation is a crucial precondition and a firm basis for the necessary progression and cultivation of the achievement of goals, as well as for the inspirational values of the organization. Furthermore, motivation can be defined as a constantly functioning driver, carrier, and harmonizer of permanent psychic energy, as well as a reason for persistently and enthusiastically performing appropriate activities. Motivation determines the readiness and willingness of all actors in a process (employees and managers). It determines the anchoring and growth of future success; in short, the sustainability of the organization(s). Moreover, sustainability connects present responsibility, effectiveness and profitability with the future, and their potential achievement. It is motivation, in particular, that is the bridge between them.

Taking the perspective described above, a paradigm of sustainability can be considered to be important and relevant for both human resource management (HRM) $[16,17]$ and-the most recent philosophy in the area-human potential development (HPD) [18]. Sustainable HRM refers to the socially responsible management of human resources and defines actions related to human capital that any organization could (should) perform to state that their management of employees is sustainable [7]. According to Ehnert, " ... sustainable HRM is the pattern of planned or emerging human resource strategies and practices intended to enable organizational goal achievement while simultaneously reproducing the human resource (HR) base over a long-lasting calendar time and controlling for self-induces side and feedback effects of HR systems on the HR base and thus on the organization itself ..." [19] (p. 74).

Human potential development, based on strategic, decisional and motivational perspectives, regards employees and managers as owners of their overall potential (in terms of aspects such as knowledge, skills, talent, enthusiasm, motivation, ... ): "They decide whether or not they can transfer their potency to their performance and organization" [19]. Sustainable HRM or HPD can contribute to both efficiency and societal performance goals [20]. This means, from a sustainability perspective, organizations must not only attract and retain talented human potential, but also sustain and retain human potential that is healthy and productive [19], highly motivated and loyal.

Generally, numerous authors have argued that taking the right decisions in the area of motivation is important. According to Maslow: "Any motivated behavior, either preparatory or consummatory, must be understood to be a channel through which many basic needs may be simultaneously expressed or satisfied. Typically, an act has more than one motivation ... " [21] (p. 370), for example; Deci, Koestner and Ryan: "Motivation derives from internal and external sources that operate on differing time scales, and that can complement or compete with one another to influence both the duration and quality of behavioral performance ... " [22]; Rosak-Szyrocka: "Motivation of working activity is much more complex since different people have different needs and desires which means they are differently motivated ... " [23] (p. 103); James and Rentsch: "Intervening between the motives, and the behaviors they stimulate, are various affective and cognitive mechanisms that shape and sustain the direction, intensity, and perseverance of the motivated behavior ... " [24] (p. 223); Hill: "While powerful and more or less universal motivators exist, every individual is different ... " [25] (p. 4). However, other than similar statements regarding the complexity of effective motivation, studies aimed at complex and intentional decision making processes orient primarily toward building and retaining sustainable working motivation still are absent in the current literature.

The aim of this article is, therefore, to focus attention especially on the dynamics and content of the decision making process in motivating human potential in three countries of Central Europe. The concept of sustainability is related to the concept of sustainable human resource management (sustainable human potential development), and, subsequently, the concept of responsibly sustainable motivation is deduced from the concept of motivation linked with the concept of managerial decision 
making in the area of work motivation. A problem, solved in the article, consists of the explanation of selected attributes and components of effective decision making regarding motivation (such as the decision making process performed when/while motivating employees and managers), defined here as a crucial precondition of building the sustainability of organizations. The main research goals are defined as follows: (1) Disclose the components that have to be respected in decision processes; (2) Define the principles and mechanisms that need to be kept during decision making; (3) Research the impacting factors that influence and determine the resultant level of perceived motivation.

Using analysis, synthesis and generalization of the theoretical knowledge, the first part of article presents decision making in relation to human potential motivation, distinguishing between decisions that indirectly (involuntarily) influence motivation and those decisions that are directly aimed at influencing motivation. The following subchapter of the first section is, subsequently, devoted to examining sustainable and responsible motivation.

The second (empirical) part of the article presents the results of sociological questioning that was done for the sample of employees and managers of Slovak, Lithuanian and Polish organizations regarding decision making for motivating. Specifically, the importance of adequate decisions when motivating human potential is examined (through the confirmed interdependency between the decisions to apply the highest qualitative level of key processes of human potential development versus the perceived resultative motivation); the most important factors are identified that decide the changeability of perceived motivation (change of past motivation toward present one). This part of the article also contains a proposed content-component model of decision making in affecting and building sustainable motivation.

\subsection{Decision Making and Human Potential Motivation}

Based on shifting of the science in the area of human resources to the science of human capital or even human potential [26-30], the key idea is that decision making concerning HR needs to change and this change represents a new decision science—organizations must make better decisions regarding their human assets [16]. This means that, when creating conditions and mechanisms for achieving the sustainable competitive advantage, " ... the importance of human factor has to be underlined and contained in the decision making processes ..." [31] (p. 76). Such a trend can be referred to as 'responsible competitiveness' or 'corporate sustainability' [1] in the context of where the future success lies in sophisticated decision making connected with the motivations existing in organizations and their surroundings.

"Decision making as one of the basic cognitive processes of human behaviors represents a choice of preferred option or a course of actions from among a set of alternatives based on certain criteria ... " [32] (p. 124). Decision making is an important subpart of human potential development and must not be simplified, especially in situations when decisions taken have a great impact on employees [33]. This means that adequate adjudicative principles and methods must be utilized.

The principles of variability and flexibility, in the extent to which the individuals permit emotional influences to guide their decisions, are crucial [34], for example. Bono draws attention to multi-variant and creative decision-taking: "Too often the decision making process is shown as a list of fixed alternatives between which a decision has to be made. We are not easily satisfied with the obvious. We multiply alternatives before choosing between them" [35]. This leads to the application of multiple criteria in motivational decision making. Additionally, Drucker's (2001) idea is interesting: " . . the effective executives know when a decision has to be based on principle and when it should be made pragmatically, on the merits of the case. They know that decision making has its own systematic process and its own clearly defined elements" [36] (p. 2). During this process, it is necessary to systematically collect all information and knowledge, transform them into multivariate solutions, evaluate these solutions precisely, and take the resulting decisions responsibly [30]. The evaluation criteria's degree of elaboration forms the quality of managerial decisions and the cumulative effect of all directions depends on them [37]. 
According to many authors, three basic groups of the methods can be used in the area of decision making: quantitative, qualitative and heuristic [38-40]. These mentioned groups and particular methods might be used appropriately within decision making in the area of work motivation. However, in the case of a flawless application of any method, it is necessary to respect the limits of human thinking. According to Simon, rational responses to the environment characterize decision making, generally. However, at points—often important points—rationality fails and, as a consequence, there is a mismatch between the decision making environment and the choices of the decision maker. Simon refers to this mismatch as 'bounded rationality showing through' [41].

Building on the ideas mentioned above, two basic types (or even dimensions) of decision making can be distinguished. These can be characterized by the conscious as well as unconscious influence of motivation (inspired by [42]):

1. Decision making performed in other organizational areas that indirectly affects (positively or negatively) work motivation, such as decisional processes, which result in indirect consequence-orientated decisions touching motivation;

2. Decision making that intentionally and sustainably improves motivation, like a decision process which results in direct, procedurally satisfied, motivational decisions.

It is important to point out that both types of decision making processes must be performed. This basis interconnects all organizational departments (marketing, production, human potential, ... ) as well as all levels (top, middle and operational) across the whole organization and emphasizes the necessity of thorough coordination and common effort by all of the organization's members and partners.

\subsubsection{Consequentially Orientated Decisions Affecting Motivation}

The first dimension of the decision making processes includes all decisions taken in the organization-in any of the organizational processes or departments, such as in marketing, production, logistics, finance, or innovation. These are the decisions with an impact on motivation that varies, making them difficult to predict because they are aimed at primarily improving the area in which they are taken (like finance). The impact of such decisions on motivation is only secondary. However, the impact is real: " ... decisions regarding global geopolitical events and competitive postures motivate and affect economic and financial policies of the state and organizations ... " [43] (p. 158). Considering the area of organizational finance, the decisions regarding a selection of the way of financing an organization's development, such as decisions regarding sources of financing and decisions concerning investing ex ante or ex post [44], affect the financial processes and, thus, both the work and motivation of employees of this department. Thus, when the department gets fewer financial resources for its development, it automatically reduces investment in education and development. Conversely, when the department receives an increased financial budget, it might decide to implement new systems of motivation, development, career growth, ergonomics, etc. Decisions regarding the appropriate targeting of marketing communication and new forms of sales [18,45], decisions concerning the application of new innovations [46] or decisions to implement the Japanese production approach, Kaizen [47], influence the motivation of considered employees too. A new production control system might require a greater self-control, compliance with higher quality standards, or material savings, and, therefore, a greater responsibility and motivation not only for managers but also for employees.

Thus, an important fact is, although most managerial decisions inside an organization are not directly focused on motivation, almost all of them influence motivation indirectly. Fear of applying any organizational regulation or implementing any planned change affects the motivation very strongly [48-50], for example. Performance can be increased significantly if the relevant structures and systems will positively encourage such activity (or at least not hinder) [51], for example. A job in a new production facility expects adoption of a new manufacturing process and its specifics [52]. This has to be 'absorbed' by the employee. S/he has to find a reason to apply a new approach. S/he has to find the courage to embark on a new style of work. $S /$ he must abandon long-term, routine procedures that have 
often been customary since the beginning of his or her career. All of the aforementioned psychological motions clash with the individual's personality and motivation. However, this intrapersonal collision must not adversely affect the employee's resulting work performance and the quality and quantity of his or her outcomes.

Summarizing the opinions regarding the importance of decisions taken in other professional areas/sections of an organization and their consequences on motivation, the need for decision-based and responsible management arises. According to Frankel, “... futures oriented, decision-based management is designed to make every member of an organization equally important in the running of the organization ... " [53] (p. 24). Generally, it can be noted that the quality of all decisions taken in all organizational areas or departments (production, marketing, finance, development, logistics, quality and so on), or the quality of decision making performed by managers and professionals of the organization, affects the motivation of all the involved members of the organization directly or indirectly, in a way that is stronger or weaker, short-term or longer-term [30,54].

\subsubsection{Procedurally Contented Decision Making Improving Motivation}

According to Albers, " ... managerial decisions have been categorized as planning and motivational decisions ..." [55] (p. 553). Therefore, the second dimension of decision making processes includes all decisions taken in organizations that are primarily and directly aimed at the improvement of motivation. These are decisions with predictable and serious effects on the resultant quality and content of motivation.

This means, when cultivating all the motivations in organizations, it is essential to create conditions for inspiring and sustaining the motivation of all employees and managers. This can be achieved through a perfectly functioning system of human potential development and motivation (HPD\&M). The system of human potential development and motivation is based on the philosophy of human potential development and links it with the deliberate influence of motivation. Using this understanding, all processes of human potential development are carried out with the motivational accent and the intention to directly improve, not only the working potential of each individual, but, above all, his or her motivation [56]. Such systems should connect the vision, objectives and all strategies of the organization and must be characterized by mastered managerial decisions performed in, and regarding all crucial HPD\&M processes, procedures, measures, etc. Such decisions concerning HPD\&M might be considered as professionally advanced and, as such, they influence the whole process of decision making regarding these processes and absolutely respect all prospects and aspects of motivation.

Taking a detailed viewpoint, these decisions must be based on an in-depth analysis of situation parameters as well as a comparison and assessment of risks and effectiveness of any decisional variant and always take the best quality solution in each of the crucial HPD\&M processes. The attention of this paper is, therefore, focused on the following crucial processes: leadership, communication, appraisal, and creating an atmosphere of trust. The analytical section will compare the level/quality of the decisions in listed processes (such as the decision of a manager or leader to perform the best quality of such a process) with the level of obtained and perceived motivation.

This means that the advanced HPD\&M decisions lead to the application of creative styles of leadership $[57,58]$ and not to the application of autocratic or dictatorial styles [48]. It must form an inspirational organizational culture [59,60] and not a rigid and impersonal culture [61]. It must replace the feelings of fear or dislike [62] by feelings of progress experienced [63]. Such a system of HPD\&M must enable an employee to have dignity [64], pride [65], happiness [66,67], joy from work done [68], mutuality [69], balance in monetary incentives [70] with nonmonetary and more.

Naturally, such qualitative values/measures are best predisposed and supported by the highest quality level of HPD\&M decisions capable, to build conditions and overall possibilities for advancing the motivation from the short-time and egoistic level to the level of sustainable, permanent and common motivation. Achieving the parameters of a particular organizational environment that will transform the original motivation to motivation of a richer content or even a transcendent level [71-73] 
should be based on absolute high-quality processes of decision making. The goal of this must be to disclose, understand, name, improve, strengthen, and especially harmonize all the motivations.

\subsection{Sustainably Responsible Motivation}

Sustainability represents " ... achieving success today without compromising the needs of the future ..." [74] (p. 129) and focuses on providing the best outcome for both human and natural environments [75]. Conversely, motivation is an inner state of the soul of man that compels him or sets him in motion [76]. Motivation "... stems from the sequence of events that moves from motives or anticipated incentives to end-states where motives are satisfied or incentives are attained ... " [77] (p. 10) and motivation study concerns all conditions that exist within the person and within the environment and culture that explain 'why one wants what s/he wants' and 'why one does what s/he does' [78]. It means " ... the motivation is the drive that energizes, sustains, and directs a person's behavior ... " [79] (p. 165).

Motivation is often understood as a description of goal-oriented behavior. It includes all processes of initiation, maintenance, or change in the psychological and physiological activity [80]. "The goal of the motivated behavior is to fulfill a specific need or desire ... " [81] (p. 4), while " . . any behavior tends to be determined by several or all of the basic needs simultaneously rather than by only one of them ... " [82] (p. 71). Taking a more sophisticated viewpoint, Kanfer and Chen portray motivation " $\ldots$ as a time-linked set of recursive and reciprocal affective, behavioral and cognitive processes and actions that are organized around an individual's goals ... " [83] (p. 7). Recursion and cognition, as unique elements or traits of understanding and application of the motivation, are emphasized in other scientific works also [84-86], and push motivation to the level in which the decision making and its rightness play an extraordinarily important role.

According to Chen and Kanfer, " ... perceptions of the environment, motives, attitudes, cognitions, and affective states are posited to contribute to motivation through their influences on what an individual chooses to do (i.e., goal choice) as well as the strategies by which the individual seeks to accomplish cognized goals (i.e., goal striving) ... " [87] (p. 228). Relating to presumptions of the article, this means that motivation actually can be understood as a " ... decision making process in which individuals choose and pursue course of action ..." "[83] (p. 11). However, not only the decision making of others impacting someone's motivation is relevant. Perhaps, the decision making of an individual who directly affects his or her own motivation is more important, especially from the viewpoint of building sustainable and responsible motivation.

Continuing the research of possibilities for an appropriate definition of sustainably responsible motivation, Maslow's thoughts on human motivation [21], although defined nearly 70 years ago, might be considered as inspirational and still correct to this day. Certainly, from the prospect of sustainability, the cognitive, aesthetic and, especially, transcendent needs defined by Maslow are now extraordinarily attractive. Strongly urgent is the desire " ... to become everything one is capable of becoming ... " [82] (p. 64). The need to become a more valuable being (expert, man, employee, manager) assumes a high degree of responsibility for one's own performance, development, and motivation. It puts self-motivating on an even higher level and systematically links it to self-responsibility. However, this level of needs and desires requires and, simultaneously, would be based on the recent shape of managerial professionality and responsibility for decision making when motivating oneself and motivating others. The result of decision making, characterized by such traits could be considered a 'sustainably responsible motivation'.

The sustainably responsible motivation contains and explains the process of effectively achieving sustainable motivation, essentially motivation that is firm, lasting, constant, permanently renewed, improved and strengthened, and brings new values and strategic competitive advantages, on the one hand. This term contains and explains the character and quality of responsibility that is activated and applied in any decision that relates to influence of the motivation, on the other hand. Such responsibility has to be felt as absolutely natural and simultaneously obligatory for all managers and HR specialists. 
When building and having responsible and sustainable motivation, the individual decides permanently about the structure (categorization) of his/her motives as well as the strength (intensity) of his/her motives. One also decides what motives one will adapt his/her behavior, what motives $\mathrm{s} /$ he will exclude from his/her motivational system, and more. This process is mostly fully conscious, but it is often a routine-unconscious and automatic. Obviously, the inner process of motivation is invisible from the standpoint of other participants in these situations. This does not mean, however, that this process is simple [30].

This sustainably responsible motivation reflects the necessity to be fully aware of all possible subsequent responses and reactions of all involved individuals or groups to all decisions taken when motivating human potential. Due to this, "... organizations must update and renew incentives that foster and reward vision and creativity, and encourage innovation and risk taking in decisions and subsequent actions ... " [53] (p. 39). The most important features of all motivational or incentive programs are their objectivity and fairness and the prevention of any forms of protégé or disadvantage because "... people do not value only their own reward in isolation, but also compare their own set-point with reference to others ... " [81] (p. 17). Additionally, if qualified experts perceive that their work is not important, their zeal for work soon wears off and experts turn into people that only wait for work to end [88].

These aforementioned warnings lead to the fact that the intensity and overall profile of perceived motivation reflects the success in harmonizing the intra-motivational with the inter-motivational processes. According to many authors, such as Matuska, " ... the internal motivation is generally stronger than external one and always wins in competition with external pressure because it relates to the nature of human being to value free choice and own will ... " [89] (p. 84). Although this opinion is true, the senior staff, who impact their own and others' motivation, must build the conditions that enable, help to establish and retain the fundamentals and strength for everyone's internal motivation. When the environment of intrinsic motivation is created, in the words of Kulkarni: "If the leaders and employees are emotionally connected with the organization and passionate about the goal and objectives, they will bring sustainable growth ..." [65] (p. 86). Therefore, as in all the previous considerations, this creative-building process is conditioned by advanced and responsible managerial decision making regarding motivating oneself and others.

Taking an interest in individual needs and aspirations is a redundant parameter for leveraging sustainable motivation [90]. Naturally, when examining the overall potency and performance possibilities of all individuals (understood as unique personalities) and all groups or teams (understood as a unique connection of several individual personalities), the themes of personality clashes and work style differences [91] are discussed. Considering this, " ... the management of intrinsic motivation is more demanding than that of extrinsic one ... " [92] (p. 69), especially because the area and depth of intrinsic motivation is complicated by existence of an ego-involved motivation. "With external incentives alone, a sustainable motivation cannot be achieved ... " [92] (p. 70). A perfect combination of the extrinsic, intrinsic and ego-involved motivation $[22,89,93,94]$ is induced through the best decisions, in other words. Such a situation might understand achieved motivation as responsibly affected and sustainably formed.

\section{Material and Methods}

“Understanding how individuals integrate incentives and their role in decision making and motivational processing has theoretical and practical implications, particularly for HRM practices that seek to promote engagement and build new behavior patterns ... " [83] (p. 15). Although Mathe, Pavie and O'Keeffe present that " ... leveraging sustainable motivation at work is supported by strong organizational values of fairness, transparency and accountability ... " [90] (p. 88), a spectrum of measures for activating sustainable motivation defined by Finke and Will is more detailed; authors emphasize especially: comprehensive management of communication, development of competencies, adaptation of managerial systems (leadership), and integration through both task orientation and participation [92] (pp. 76-84). Naturally, to be responsible, the organization must have dynamic mechanisms of dialogue with employees [7]. 


\subsection{Study Design and Instruments}

Based on the preference for thorough effort, the authors also incline toward an extended understanding of measures that need to be examined when dealing with sustainable motivation. The authors, therefore, decided to perform a sociological survey on the sample of respondents from three European countries: Slovak Republic, Poland, and Lithuania. A Structured Questionnaire on Motivation [95] was chosen as the analytical tool. Original questionnaires were analyzed on the grounds of repeated surveys and improvements of the whole research methodology were systematically included. Two almost identical versions of the questionnaire were developed. Differences consisted of respecting the character of the job/position performed by the respondent (employee versus manager).

The content of the questions (17 for employees and 18 for managers) examined the approaches, processes, elements, tools and decisions related to motivation and motivating: awareness, leadership, appraisal and remuneration, communication, atmosphere, level of motivation, self-motivation, motivation programs, etc. Three types of scale were used: (a) Likert's 5-point scale for classic questions and questions with pre-defined statements; (b) a 2-point scale for resolute (exclusion) questions; and (c) a scale 1-10 for assessment questions. Used forms of the questionnaire for employees and managers are presented in the Annex. Interviewing was performed in the time period of January-February 2018 by personally contacting employees and managers with written (email) or personal requests to complete the prepared electronic questionnaire. This method was chosen especially to achieve the highest expected return and more transparent processing of collected data (see supplementary).

\subsection{Sample}

The selection of countries for this article (Slovak Republic, Lithuania, and Poland) was based on the long-term cooperation of researchers from these countries in area of human resources and based on similarities of these countries in numerous areas. Characteristic identifiers of respondents in this study are age, gender, education, length of practice, size of organization, region and industry sector. Based on the identification of respondents via basic characteristics, it was possible to state that the sample was multidimensional because the selected sample had various spreads of individual characteristics. Other demographic and economic factors also proved the similarities between the countries (Table 1).

Table 1. Characteristic attributes of selected countries in 2017.

\begin{tabular}{ccccc}
\hline Characteristic & Details & Slovakia & Lithuania & Poland \\
\hline \multirow{2}{*}{ Median age } & Male & 38.8 & 39.7 & 39.0 \\
& Female & 42.3 & 47.1 & 42.4 \\
& Total & 40.5 & 43.7 & 40.7 \\
\hline Birth rate & Births/1000 pop. & 9.7 & 9.9 & 9.5 \\
\hline \multirow{3}{*}{ Life expectancy at birth } & Male & 73.7 & 69.7 & 73.9 \\
& Female & 81.1 & 80.7 & 81.8 \\
& Total & 77.3 & 75.0 & 77.8 \\
\hline GDP_per capita (PPP) & $\$$ & 32.9 & 31.9 & 29.3 \\
Production growth rate & $\%$ & 3.5 & 2.8 & 4.2 \\
Unemployment rate & $\%$ & 7.7 & 6.7 & 4.5 \\
\hline \multicolumn{2}{c}{ Source: [96-98]. }
\end{tabular}

The target group of the whole study was the working population of the Slovak Republic (2,542,600 employees), of Poland (16,344,000 employees), and Lithuania (1,347,100 employees). A statistical approach was used to determine the size of the sample $(n)$ and tolerance of error $(E)$, mostly due to the accuracy of evaluated results. $N$ was the basic set, $r$ was the share of answers the research team was interested in, and $Z(c / 100)$ was the critical value for the confidence level $C[38,99]$ :

$$
x=Z\left(\frac{c}{100}\right)^{2} r(100-r),
$$




$$
\begin{gathered}
n=\frac{N x}{\left((N-1) E^{2}+x\right)}, \\
E=\sqrt{\frac{(N-n) x}{n(N-1)}} .
\end{gathered}
$$

The recommended selected sample for individual countries was, according to statistical calculation, 385 respondents. Using the countries of Slovakia; Poland; and Lithuania, the numbers of participating respondents decreased the estimation of error to $4.38 \% ; 4.96 \%$; and $6.52 \%$, respectively.

\subsection{Participants}

The numbers of respondents who participated in the survey were: Slovakia $n=500$; Poland $n=$ 390; Lithuania $n=226$ respondents. The composition of respondents indicates a higher willingness of women (especially in a group of employees) to participate in the survey. Regarding Slovakia and Poland, the most frequent group was employed in the 18-28 age group-while, in Lithuania, the category was $40-50$ years. This also corresponds with the willingness of the respondents, but also with the possibility of the authors, to actually ask respondents to participate in the survey (mostly former students-graduates of universities, currently working in various types of organizations). A more detailed description of the respondents is shown in Table 2.

\begin{tabular}{|c|c|c|c|c|c|c|c|c|c|c|c|c|}
\hline \multirow{3}{*}{ Age } & \multicolumn{4}{|c|}{ Slovakia $(n=500)$} & \multicolumn{4}{|c|}{ Poland $(n=390)$} & \multicolumn{4}{|c|}{ Lithuania $(n=226)$} \\
\hline & \multicolumn{2}{|c|}{ Employees $80 \%$} & \multicolumn{2}{|c|}{ Managers $20 \%$} & \multicolumn{2}{|c|}{ Employees 88\% } & \multicolumn{2}{|c|}{ Managers $12 \%$} & \multicolumn{2}{|c|}{ Employees 73\% } & \multicolumn{2}{|c|}{ Managers $27 \%$} \\
\hline & Male & Female & Male & Female & Male & Female & Male & Female & Male & Female & Male & Female \\
\hline $18-28$ & 39 & 132 & 12 & 11 & 34 & 172 & 4 & 5 & 5 & 13 & 0 & 1 \\
\hline $29-39$ & 47 & 72 & 9 & 16 & 21 & 75 & 7 & 12 & 9 & 34 & 1 & 4 \\
\hline $40-50$ & 27 & 44 & 27 & 19 & 7 & 27 & 5 & 10 & 10 & 38 & 6 & 20 \\
\hline $51-61$ & 16 & 19 & 3 & 2 & 0 & 5 & 2 & 2 & 8 & 38 & 5 & 18 \\
\hline $61>$ & 4 & 0 & 1 & 0 & 0 & 1 & 0 & 1 & 6 & 5 & 2 & 3 \\
\hline Total & 133 & 267 & 52 & 48 & 62 & 280 & 18 & 30 & 38 & 128 & 14 & 46 \\
\hline
\end{tabular}

Table 2. Basic characteristics of respondents: Slovakia, Poland and Lithuania.

\subsection{Procedure-Test of Reliance}

During the test of reliance, the reliability of individual questions was measured using the Cronbach Alpha Test. These are questions about awareness, fair appraisal, open communication, positive atmosphere at the workplace, and level of motivation toward selected realities (orientations). Table 3 shows that it is possible to see results of the reliability for the first group of questions (questions that had answers: yes, mostly yes, average, mostly no, and no) and for the second group of questions about felt motivation (questions that had answers: high, rather high, average, rather low, and low).

\begin{tabular}{|c|c|c|c|c|c|}
\hline Characteristics & Processes/Motivational Focuses & Corrected Item-Total Correlation & Cronbach's Alpha If Item Deleted & Cronbach's Alpha & $n$ of Items \\
\hline \multirow{4}{*}{ Group-Processes } & Awareness & 0.568 & 0.835 & - & - \\
\hline & Appraisal & 0.712 & 0.795 & - & - \\
\hline & Communication & 0.742 & 0.779 & - & - \\
\hline & & Total & & 0.846 & 4 \\
\hline \multirow{3}{*}{$\begin{array}{l}\text { Group-Motivation } \\
\text { orientation }\end{array}$} & Quality work & 0.730 & 0.879 & - & - \\
\hline & Improve of skills & 0.761 & 0.867 & - & - \\
\hline & New ideas & 0.796 & 0.854 & - & - \\
\hline
\end{tabular}

Table 3. Reliability of questionnaire.

The degree of reliability was higher than 0.8 between both groups of questions, which indicates a great level of reliability and, therefore, great consistency in the selected sample. The column, "Cronbach's Alpha if item deleted", shows that, in the case of deleting individual questions from the questionnaire, the reliability of the questionnaire would slightly decrease. This fact also confirms the consistent logic of questions. The value of "Corrected item-total correlation" shows high values for individual questions, which demonstrates a dependency between individual questions. 


\section{Data Analysis and Results}

With regards to main research goals (a) disclose the crucial components of decision process in motivating; (b) define the principles and mechanisms of such decision-making; (c) search the affect-capable factors influencing and deciding on the motivation, and data were collected and processed.

\subsection{Data Analysis}

Several types of analyses were used to process the collected data. First, with the aim to determine the level of motivation, frequencies of the expressed levels of motivation were studied, including the mean and standard deviation between groups of respondents in each country. These findings were then used to analyze the impact of leadership, performance appraisal, communication, and building atmosphere on the intensity of perceived motivation. The mutual impact was examined through the following tests: Pearson Chi-Square, Likelihood Ratio, and Linear-by-Linear Association. Consequently, with the intention of determining the order and examining the differences of the most important factors in the individual countries that decided to change the motivation of respondents in terms of time development, the hypotheses $\mathrm{H} 1$ and H0 were determined. Through Wilcoxon's test, the relevance of H1 was examined and confirmed. Finally, through frequency analysis, respondents' recommendations relating to the potential increase in their work motivation were analyzed.

The comparison of the level of perceived motivation toward quality work, toward a constant increase in the level of professional knowledge and skills, toward new ideas and increasing the effectiveness of the processes being used, and toward cooperating with superiors is shown in Table 4 . Table 4 presents the basic focuses of motivation, degree/level of perceived motivation, frequency of respondents in all studied countries, with the classification of groups of employees and groups of managers, the calculated mean of the perceived motivation for each motivational focus, and the standard deviation.

The Slovak, Polish and Lithuanian respondents felt the strongest motivation toward quality work. The managers' responses were more consistent than those of employees in all countries (as generated using the standard deviation). The biggest difference between the employees' and the managers' responses was their view of their mutual cooperation. Regarding Lithuanian respondents, it can be seen that the overall level of motivation was slightly lower than that of the other respondents from Slovakia and Poland. The highest compliance of respondents' answers can be observed in the evaluation of motivation toward quality work.

Regarding the spread of respondents, the smallest deviation and, thus, the most consistent answers are those of the Polish managers. The least consistent answers, overlapping by more than one point, can be observed in the Slovak employees and very similarly with Lithuanian employees, which signals a heterogeneity of respondents within a group of employees, which was higher than the one of managers.

Based on these results, it can be observed that managers (no matter what industry they are from) feel almost the same level of motivation. Employees showed mild heterogeneity, which possibly could be further examined in consideration of work field (industry), gender, age, or practice.

The level of motivation was related to key HPD\&M processes, with an intention to search for the impactful factors that usually influence motivation (third research goal). The dependence of the level of motivation to the aforementioned orientations related to key processes was studied: creative leadership, fair work performance appraisal, open and friendly communication, and creating an atmosphere of trust, openness, and belongingness (Table 5). A correlation was calculated using the Pearson chi-square test. It was shown in all cases that the selected correlation was of high significance, as the asymptotic significance was 0.000 .

The calculated chi-square for all countries and processes was significantly higher than the table value (at degrees of freedom 8 and 16; and level of significance 0.05 ). This indicates a clear interrelation and impact by individual processes to the level of motivation as well as the level of motivation to implement and perceive selected key processes. 
Table 4. Perceived motivation: comparison of Slovakia, Poland and Lithuania.

\begin{tabular}{|c|c|c|c|c|c|c|c|c|c|c|c|c|c|}
\hline \multirow[b]{2}{*}{ Motivation Focus } & \multirow{3}{*}{ Degree of Motivation } & \multicolumn{4}{|c|}{ Slovakia } & \multicolumn{4}{|c|}{ Poland } & \multicolumn{4}{|c|}{ Lithuania } \\
\hline & & \multirow{2}{*}{$\begin{array}{c}\text { Employees } n=400 \\
\text { Freq. }\end{array}$} & \multicolumn{3}{|c|}{ Managers $n=100$} & \multicolumn{2}{|c|}{ Employees $n=342$} & \multicolumn{2}{|c|}{ Managers $n=48$} & \multicolumn{2}{|c|}{ Employees $n=166$} & \multicolumn{2}{|c|}{ Managers $n=60$} \\
\hline & & & $\%$ & Freq. & $\%$ & Freq. & $\%$ & Freq. & $\%$ & Freq. & $\%$ & Freq. & $\%$ \\
\hline \multirow{4}{*}{ Motivation to quality work } & High & 167 & 41.75 & 61 & 61.00 & 116 & 33.92 & 28 & 58.33 & 48 & 28.92 & 30 & 50.00 \\
\hline & Rather high & 156 & 39.00 & 30 & 30.00 & 154 & 45.03 & 17 & 35.42 & 70 & 42.17 & 23 & 38.33 \\
\hline & Rather low & 21 & 5.25 & 0 & 0.00 & 4 & 1.17 & 0 & 0.00 & 3 & 1.81 & 0 & 0.00 \\
\hline & Low & 9 & 2.25 & 0 & 0.00 & 9 & 2.63 & 0 & 0.00 & 6 & 3.61 & 1 & 1.67 \\
\hline \multirow{2}{*}{\multicolumn{2}{|c|}{$\begin{array}{c}\text { Mean } \\
\text { Standard deviation }\end{array}$}} & 1.87 & \multirow{2}{*}{\multicolumn{3}{|c|}{$\begin{array}{l}1.48 \\
0.66\end{array}$}} & \multirow{2}{*}{\multicolumn{2}{|c|}{$\begin{array}{l}1.94 \\
0.89\end{array}$}} & \multirow{2}{*}{\multicolumn{2}{|c|}{$\begin{array}{l}1.49 \\
0.62\end{array}$}} & \multirow{2}{*}{\multicolumn{2}{|c|}{$\begin{array}{l}2.09 \\
0.96\end{array}$}} & \multirow{2}{*}{\multicolumn{2}{|c|}{$\begin{array}{l}1.65 \\
0.80\end{array}$}} \\
\hline & & 0.97 & & & & & & & & & & & \\
\hline \multirow{4}{*}{ Motivation to improve knowledge and skills } & High & 130 & 32.50 & 53 & 53.00 & 138 & 40.35 & 30 & 62.50 & 39 & 23.49 & 18 & 30.00 \\
\hline & Average & 66 & 16.50 & 14 & 14.00 & 61 & 17.84 & 6 & 12.50 & 39 & 23.49 & 9 & 15.00 \\
\hline & Rather low & 23 & 5.75 & 2 & 2.00 & 5 & 1.46 & 0 & 0.00 & 8 & 4.82 & 2 & 3.33 \\
\hline & Low & 16 & 4.00 & 0 & 0.00 & 10 & 2.92 & 0 & 0.00 & 7 & 4.22 & 1 & 1.67 \\
\hline \multirow{2}{*}{$\begin{array}{c}\text { Mean } \\
\text { Standard deviation }\end{array}$} & & 2.08 & & 1.65 & & \multirow{2}{*}{\multicolumn{2}{|c|}{$\begin{array}{l}1.90 \\
0.95\end{array}$}} & \multirow{2}{*}{\multicolumn{2}{|c|}{$\begin{array}{l}1.53 \\
0.73\end{array}$}} & \multirow{2}{*}{\multicolumn{2}{|c|}{$\begin{array}{l}2.22 \\
1.00\end{array}$}} & \multirow{2}{*}{\multicolumn{2}{|c|}{$\begin{array}{l}1.97 \\
0.86\end{array}$}} \\
\hline & & 1.04 & & 0.80 & & & & & & & & & \\
\hline \multirow{5}{*}{ Motivation to new ideas } & High & 64 & 16.00 & 30 & 30.00 & 80 & 23.39 & 17 & 35.42 & 22 & 13.25 & 21 & 35.00 \\
\hline & Rather high & 161 & 40.25 & 51 & 51.00 & 157 & 45.91 & 28 & 58.33 & 63 & 37.95 & 24 & 40.00 \\
\hline & Average & 122 & 30.50 & 14 & 14.00 & 77 & 22.51 & 2 & 4.17 & 56 & 33.73 & 13 & 21.67 \\
\hline & Rather low & 30 & 7.50 & 3 & 3.00 & 16 & 4.68 & 1 & 2.08 & 16 & 9.64 & 1 & 1.67 \\
\hline & Low & 23 & 5.75 & 2 & 2.00 & 12 & 3.51 & 0 & 0.00 & 9 & 5.42 & 1 & 1.67 \\
\hline \multicolumn{2}{|l|}{$\begin{array}{c}\text { Mean } \\
\text { Standard deviation }\end{array}$} & 2.47 & & 1.96 & & \multicolumn{2}{|c|}{2.21} & & & & & & \\
\hline & High & 79 & 19.75 & 45 & 45.00 & 86 & 25.15 & 18 & 37.50 & 25 & 15.06 & 17 & 28.33 \\
\hline & Rather high & 162 & 40.50 & 41 & 41.00 & 143 & 41.81 & 21 & 43.75 & 53 & 31.93 & 27 & 45.00 \\
\hline Motivation to cooperate with superior & Average & 103 & 25.75 & 10 & 10.00 & 87 & 25.44 & 9 & 18.75 & 60 & 36.14 & 13 & 21.67 \\
\hline & Rather low & 39 & 9.75 & 3 & 3.00 & 11 & 3.22 & 0 & 0.00 & 16 & 9.64 & 2 & 3.33 \\
\hline & Low & 17 & 4.25 & 1 & 1.00 & 15 & 4.39 & 0 & 0.00 & 12 & 7.23 & 1 & 1.67 \\
\hline Mean & & 2.38 & & 1.74 & & & & & & & & & \\
\hline Standard deviation & & 1.04 & & 0.84 & & & & & & & & & \\
\hline
\end{tabular}


Table 5. Correlation between perceived motivation and key processes of human potential development in Slovakia (SK), Poland (P) and Lithuania (LT).

\begin{tabular}{|c|c|c|c|c|c|c|c|c|c|c|c|c|c|}
\hline \multirow{2}{*}{ Motivation Focus } & \multirow{2}{*}{ Tested Characteristics } & \multicolumn{3}{|c|}{ Leadership } & \multicolumn{3}{|c|}{ Appraisal } & \multicolumn{3}{|c|}{ Communication } & \multicolumn{3}{|c|}{ Trust } \\
\hline & & SK & PL & LT & SK & PL & LT & SK & PL & LT & SK & PL & LT \\
\hline \multicolumn{2}{|c|}{ Degree of freedom (table chi-square coefficient at significant level 0.05) } & \multicolumn{3}{|c|}{$8(15.507)$} & \multicolumn{3}{|c|}{$16(26.296)$} & \multicolumn{3}{|c|}{$16(26.296)$} & \multicolumn{3}{|c|}{$16(26.296)$} \\
\hline \multicolumn{2}{|c|}{ Asymp. Sig. (2-sided) } & \multicolumn{3}{|c|}{0.000} & \multicolumn{3}{|c|}{0.000} & \multicolumn{3}{|c|}{0.000} & \multicolumn{3}{|c|}{0.000} \\
\hline \multirow{3}{*}{ Motivation to quality work } & Pearson Chi-Square & 76.502 & 49.277 & 27.259 & 227.841 & 93.941 & 113.114 & 132.999 & 108.679 & 100.760 & 192.656 & 105.196 & 67.341 \\
\hline & Likelihood Ratio & 77.817 & 49.864 & 29.724 & 150.494 & 75.214 & 68.634 & 104.557 & 86.610 & 64.676 & 156.734 & 91.155 & 56.149 \\
\hline & Linear-by-Linear Association & 62.014 & 31.959 & 23.986 & 117.342 & 52.218 & 51.544 & 77.966 & 63.040 & 44.559 & 121.982 & 75.168 & 39.608 \\
\hline \multicolumn{2}{|c|}{$n$ of Valid Cases (value) } & 500 & 383 & 211 & 500 & 381 & 214 & 500 & 380 & 213 & 500 & 385 & 215 \\
\hline \multirow{3}{*}{ Motivation to improve knowledge and skills } & Pearson Chi-Square & 70.414 & 44.438 & 26.160 & 182.444 & 47.528 & 130.988 & 147.951 & 78.157 & 123.583 & 134.709 & 62.804 & 75.270 \\
\hline & Likelihood Ratio & 76.053 & 43.355 & 26.358 & 141.683 & 41.139 & 85.350 & 110.797 & 60.815 & 92.932 & 122.861 & 51.258 & 62.839 \\
\hline & Linear-by-Linear Association & 57.202 & 34.573 & 21.281 & 97.868 & 27.876 & 50.692 & 80.198 & 36.939 & 55.466 & 90.640 & 35.138 & 41.292 \\
\hline \multicolumn{2}{|c|}{$n$ of Valid Cases (value) } & 500 & 380 & 211 & 500 & 378 & 214 & 500 & 377 & 213 & 500 & 382 & 215 \\
\hline \multirow{3}{*}{ Motivation to new suggestions } & Pearson Chi-Square & 107.518 & 64.072 & 33.297 & 218.369 & 81.665 & 114.600 & 193.217 & 101.609 & 124.140 & 198.136 & 107.724 & 72.654 \\
\hline & Likelihood Ratio & 117.239 & 64.998 & 32.768 & 159.314 & 66.133 & 81.884 & 147.854 & 76.117 & 98.017 & 167.868 & 92.705 & 67.446 \\
\hline & Linear-by-Linear Association & 95.708 & 58.313 & 28.099 & 109.434 & 53.111 & 52.873 & 100.283 & 56.843 & 62.208 & 119.342 & 75.298 & 51.942 \\
\hline \multicolumn{2}{|c|}{$n$ of Valid Cases (value) } & 500 & 379 & 207 & 500 & 377 & 210 & 500 & 376 & 209 & 500 & 381 & 211 \\
\hline \multirow{3}{*}{ Motivation to cooperate with superior } & Pearson Chi-Square & 133.091 & 76.258 & 53.207 & 291.071 & 132.533 & 131.040 & 174.370 & 189.949 & 144.366 & 274.270 & 135.398 & 124.884 \\
\hline & Likelihood Ratio & 142.405 & 76.230 & 49.161 & 201.736 & 91.280 & 100.348 & 134.894 & 119.407 & 113.727 & 231.467 & 117.453 & 107.303 \\
\hline & Linear-by-Linear Association & 114.184 & 68.414 & 39.229 & 148.862 & 81.020 & 73.449 & 104.392 & 91.098 & 65.955 & 174.604 & 103.385 & 73.152 \\
\hline \multicolumn{2}{|c|}{$n$ of Valid Cases (value)* } & 500 & 381 & 210 & 500 & 379 & 213 & 500 & 378 & 212 & 500 & 383 & 214 \\
\hline
\end{tabular}

* Some respondents did not answer to these questions. 
A possible change of past motivation must be researched when taking the viewpoint of the first research goal (to disclose the components that have to be respected during the decision making process when/in motivating). Due to this, the factors that decided the change in respondents' past motivation and caused their current (different) motivation were researched. Table 6 shows that respondents' answers vary from country to country. The most important factor that caused a change in motivation among Slovak employees was a significant success in work and family formation. The Polish respondents expressed that the change in motivation was caused mostly by the awareness of their own qualities and the gradual maturation of the personality. Like the Polish, the Lithuanian respondents stated that it mainly was realizing their qualities and consequently their health.

Table 6. Factors deciding on motivation change: Slovakia (SK), Poland (P) and Lithuania (LT).

\begin{tabular}{|c|c|c|c|c|}
\hline Factor of Change & Mean of ALL & Mean of SK & Mean of PL & Mean of LT \\
\hline Significant success in the work area & $29.40 \%$ & $34.60 \%$ & $31.03 \%$ & $22.57 \%$ \\
\hline Big failure in work & $6.03 \%$ & $5.00 \%$ & $10.00 \%$ & $3.10 \%$ \\
\hline Experience of joyful, pursuing event & $9.15 \%$ & $6.40 \%$ & $8.21 \%$ & $12.83 \%$ \\
\hline The success and happiness of a child & $9.03 \%$ & $4.20 \%$ & $10.51 \%$ & $12.39 \%$ \\
\hline Slow maturation and own development & $20.54 \%$ & $11.20 \%$ & $43.33 \%$ & $7.08 \%$ \\
\hline Satisfaction in partner life & $15.00 \%$ & $19.60 \%$ & $12.56 \%$ & $12.83 \%$ \\
\hline Meeting recognized, respected man & $11.07 \%$ & $12.40 \%$ & $9.74 \%$ & $11.06 \%$ \\
\hline Achieving a long-desired goal & $26.76 \%$ & $32.20 \%$ & $26.41 \%$ & $21.68 \%$ \\
\hline Starting a family & $22.44 \%$ & $44.40 \%$ & $17.18 \%$ & $5.75 \%$ \\
\hline Death of a loved one or friend & $8.84 \%$ & $18.00 \%$ & $7.18 \%$ & $1.33 \%$ \\
\hline Arising the hidden, latent need & $11.68 \%$ & $25.40 \%$ & $7.44 \%$ & $2.21 \%$ \\
\hline Long-term fatigue, stress, burn-out & $17.71 \%$ & $1.40 \%$ & $28.72 \%$ & $23.01 \%$ \\
\hline Awareness of own qualities & $27.66 \%$ & $11.20 \%$ & $44.36 \%$ & $27.43 \%$ \\
\hline Demotivating influence of superior & $12.36 \%$ & $4.00 \%$ & $15.38 \%$ & $17.70 \%$ \\
\hline Failure, unfortunate of the child & $11.76 \%$ & $31.40 \%$ & $2.56 \%$ & $1.33 \%$ \\
\hline Disappointment in partner life & $13.07 \%$ & $30.60 \%$ & $4.62 \%$ & $3.98 \%$ \\
\hline Change of job or employment & $21.46 \%$ & $14.80 \%$ & $29.23 \%$ & $20.35 \%$ \\
\hline Health and state of health & $25.16 \%$ & $25.40 \%$ & $23.08 \%$ & $26.99 \%$ \\
\hline
\end{tabular}

It can be seen from the responses that the factor of quality is the common indicator for changing motivation, either in the form of personal and working qualities or well-done work (this factor also proved to be the strongest motivator in the previous evaluation).

Based on the initial heterogeneity of respondents' answers, the importance of the difference in respondents' answers between countries and the common average was further examined. Hypothesis $\mathrm{H} 1$ and its negation hypothesis $\mathrm{H} 0$ were determined and Wilcoxon's test was chosen as the appropriate statistical method.

Hypothesis H1: The examined impact of the individual factors on the respondents is significantly different in the groups compared.

Negation hypothesis H0: The examined impact of the individual factors on the respondents is not significantly different in the groups compared.

Results of all three countries with each other and, subsequently, individual countries to the whole were compared, thus unifying all three countries' responses. To compare the data, the relative frequencies in each country were used.

Since the Wilcoxon test can handle a mixed sample of data (expressed by respondents from all three countries at the same time) to reveal deeper statistical differences in the statements [100-102], the countries were compared in pairs with one another, but also individually to the whole set of respondents.

Table 7 shows that, only in the case of comparisons of Slovakia versus all others and Lithuania versus all others, the H0 hypothesis cannot be rejected. However, in all remaining cases, the H0 hypothesis is dismissed in favor of H1. Therefore, it is possible to conclude that the respondents' answers in individual countries are indeed significantly different, as the first results of the previous evaluation have already indicated. 
Table 7. Wilcoxon test: Slovakia (SK), Poland (P) and Lithuania (LT).

\begin{tabular}{ccccccc}
\hline Characteristics & SK vs. PL & SK vs. LT & SK vs. All & PL vs. LT & PL vs. All & LT vs. All \\
\hline Positive sum & 87 & 113 & 140 & 99 & 92 & 40 \\
Negative sum & -84 & -58 & -31 & -72 & -79 & -131 \\
Test statistics & 84 & 58 & 31 & 72 & 79 & 40 \\
$\begin{array}{l}\text { Confirmed } \\
\text { hypothesis }\end{array}$ & $\mathrm{H} 1$ & $\mathrm{H} 1$ & $\mathrm{H} 0$ & $\mathrm{H} 1$ & $\mathrm{H} 1$ & $\mathrm{H} 0$ \\
\hline
\end{tabular}

Finally, to define the principles and mechanisms that needed to be kept in the motivational decision making (second research goal), the respondents were asked to propose options for senior staff that could increase their own motivation and, therefore, their willingness to increase their own performance. The answers show that the recurring factors in all three countries surveyed are fairness, justice and a human approach from the side of supervisors to employees. Country-specific recommended decisions are highlighted in Table 8.

Table 8. Suggested decisions for motivation increase: comparison of Slovakia, Poland and Lithuania.

\begin{tabular}{|c|c|c|c|c|c|c|c|c|c|c|c|c|}
\hline \multirow{3}{*}{ Suggestions } & \multicolumn{4}{|c|}{ Slovakia } & \multicolumn{4}{|c|}{ Poland } & \multicolumn{4}{|c|}{ Lithuania } \\
\hline & \multicolumn{2}{|c|}{ Employees } & \multicolumn{2}{|c|}{ Managers } & \multicolumn{2}{|c|}{ Employees } & \multicolumn{2}{|c|}{ Managers } & \multicolumn{2}{|c|}{ Employees } & \multicolumn{2}{|c|}{ Managers } \\
\hline & Freq. & $\%$ & Freq. & $\%$ & Freq. & $\%$ & Freq. & $\%$ & Freq. & $\%$ & Freq. & $\%$ \\
\hline Greater interest in employees & 184 & 46.00 & 38 & 38.00 & 157 & 45.91 & 24 & 50.00 & 65 & 39.16 & 22 & 36.67 \\
\hline Training activities and skills development & 131 & 32.75 & 25 & 25.00 & 147 & 42.98 & 15 & 31.25 & 13 & 7.83 & 4 & 6.67 \\
\hline Creating good relationship & 121 & 30.25 & 33 & 33.00 & 165 & 48.25 & 20 & 41.67 & 90 & 54.22 & 29 & 48.33 \\
\hline Higher remuneration and rewards & 160 & 40.00 & 40 & 40.00 & 251 & 73.39 & 26 & 54.17 & 97 & 58.43 & 26 & 43.33 \\
\hline Career growth and job prospects & 176 & 44.00 & 32 & 32.00 & 157 & 45.91 & 18 & 37.50 & 60 & 36.14 & 21 & 35.00 \\
\hline Participation in decisions & 76 & 19.00 & 20 & 20.00 & 56 & 16.37 & 11 & 22.92 & 30 & 18.07 & 11 & 18.33 \\
\hline Fairness, justice and humanity of superior & 310 & 77.50 & 66 & 66.00 & 168 & 49.12 & 22 & 45.83 & 76 & 45.78 & 23 & 38.33 \\
\hline Providing the necessary information & 137 & 34.25 & 23 & 23.00 & 86 & 25.15 & 5 & 10.42 & 41 & 24.70 & 11 & 18.33 \\
\hline Mutual and open cooperation & 191 & 47.75 & 40 & 40.00 & 156 & 45.61 & 18 & 37.50 & 70 & 42.17 & 27 & 45.00 \\
\hline Space for autonomy and self-realization & 166 & 41.50 & 36 & 36.00 & 77 & 22.51 & 12 & 25.00 & 35 & 21.08 & 12 & 20.00 \\
\hline Better work conditions & 56 & 14.00 & 23 & 23.00 & 137 & 40.06 & 13 & 27.08 & 40 & 24.10 & 11 & 18.33 \\
\hline Recognition for quality work & 225 & 56.25 & 43 & 43.00 & 122 & 35.67 & 13 & 27.08 & 35 & 21.08 & 15 & 25.00 \\
\hline Employee bonuses and benefits & 191 & 47.75 & 34 & 34.00 & 126 & 36.84 & 7 & 14.58 & 67 & 40.36 & 22 & 36.67 \\
\hline Improving mutual communication & 135 & 33.75 & 27 & 27.00 & 111 & 32.46 & 18 & 37.50 & 45 & 27.11 & 17 & 28.33 \\
\hline
\end{tabular}

One of the most important factors for Slovakian respondents were fairness and justice from superiors, which was not considered the biggest problem in other countries. Roughly $77.5 \%$ of Slovakian employees and $66 \%$ of Slovakian managers showed interest in this factor. Regarding Poland and Lithuania, the respondents agreed that it would be appropriate to enrich these motivational approaches and the motivational program by creating good relations and greater benefits (rewards). This finding is explained by a certain degree of rigidity and, sometimes, even by cases of unfairness of employers in Slovakia. Therefore, the justice of superiors is more urgent. Probably, the sense of injustice conveys a more solid view of employees to apply other, more creative, managerial decisions. This further emphasizes the importance of advanced decision making for motivation.

\subsection{Results}

Evaluation of the survey results brought really interesting findings. Specifically, if they were related to the results of other studies (discussed in Section 4), they illuminated the current situation in selected decision making areas for motivating the staff and managers of the three countries surveyed.

\subsubsection{Indications from Data Analysis}

Results (average intensity of perceived motivation, Table 4) document different strengths of motivation due to the different orientations of motivation on one hand, while, on the other hand, they 
show some differences in the average intensity of motivational orientations between studied countries. Additionally, it can be concluded that the level of motivation (to any of the focused areas) does not reach its maximum. This indicates a clear need to improve decision making processes in organizations. Motivation must be seen as seriously impacting the financial results or profit of an organization.

Based on the results shown in Table 5 (which related the creative leadership, open communication, fair appraisal, and built atmosphere of trust toward the level of perceived motivation), the quality of the key processes of development and motivation of human potential is indicated as one of the strongest pillars of building sustainable and responsible motivation. This result can be perceived as an alert, or inspiration, for organizational managers to understand decisions regarding motivation as multi-characteristic, influenced by many forces and facts.

The importance of factors (Tables 6 and 7) that decide or change the past motivation to a different one over time, in fact, varies from country to country. This situation is the same in a case of supposed decisions the implementation of which could improve and sustain perceived work motivation (Table 8) as well. Based on these analyses, it is possible to state that it is not favorable to use successful motivational programs from one country on employees from another country in its previous and non-changed form. Based on examined differences, it is necessary to tailor the motivational programs respecting the preferences and needs of particular employees. Not tailoring the successful programs from abroad would result in a failure of the motivational program.

\subsubsection{Model of Decision Making for Sustainably Responsible Motivation}

Achievement of sustainably responsible motivation assumes a high level of accuracy and preciseness in the decision making processes. Based on theoretical knowledge analysis and discussion, including the results of presented international examination, three groups of elements in decision making, focused on both sustainable and responsible motivation in the model (Figure 1), can be defined: (1) Components of decision-making in building sustainable motivation; (2) Decisional principles and mechanisms in building sustainable motivation; (3) Affect-capable factors in building sustainably responsible motivation.

Components of Decision-Making in Building Sustainable Motivation

- Goal (to build sustainable motivation), subjects (participants in the process, such as managers, HR experts, employees, partners, etc.), and the object of decision-making (motivation);

- Focus of decision making on solving four key problems, like setting motivational objectives, working out a motivational strategy, creating motivational programs, and performing motivational processes;

- Process and time prospects of building sustainable motivation, such as mutual and accelerative relations between and among the past, present and future decision making in the area of motivation; and the past, present and future motivations and processes of motivating;

- Methods of decision making potentially usable when deciding a process of motivating individuals and groups, like a quantitative (questionnaire, experiment, $t$-test, ... ), qualitative (Delphi method, interview, brainstorming, brainwriting, etcetera.) and heuristic classes (decision analysis, decision trees, decisions tables, and more). 


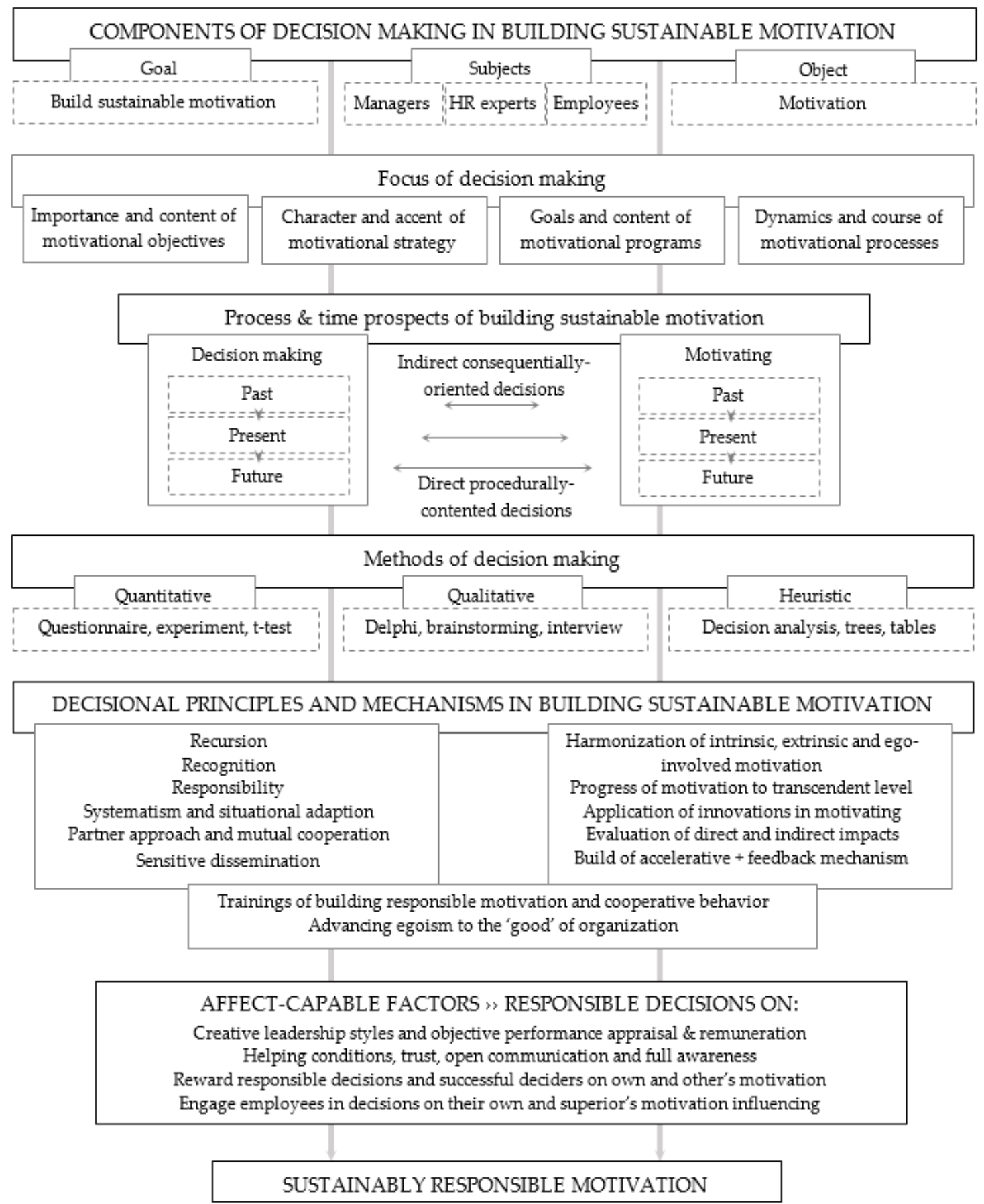

Figure 1. Content-componential model of decision-making in building sustainably responsible motivation.

Decisional Principles and Mechanisms in Building Sustainable Motivation

- Application of crucial principles such as the three Rs (recursion, recognition, and responsibility), systematism and permanent situational adaptation to changed conditions, partner approach, open cooperation, sensitive application of taken motivational decisions and measures;

- Achieving the functionality of/for advanced processes of decision making and motivating, such as harmonization of all the motivations, progressing the motivation to a transcendent level, creating and implementing innovativeness in motivating, evaluation of all positive and negative impacts, development of accelerative mechanisms and mechanisms for constructive feedback;

- Building the conditions and overall possibilities for functionality of the proposed model, like training in the area of building responsible motivation, cooperative behavior, willingness and 
readiness of persons who affect the motivation as well as processes for advancing the individual egoism for the 'good' of the organization.

Affect-Capable Factors in Building Sustainably Responsible Motivation

Taking the right managerial decisions aimed at the achievement of quality for all HPD\&M processes as high as possible, including rewards for responsible decisions and role-model deciders/impacts on motivation and, simultaneously, the engagement of participants in decision making regarding their own and their superior's motivation.

\section{Discussion}

According to Zsolnai, “ ... the responsibility perceived by the decision maker largely determines his or her choice. The greater the adequacy of the decision maker's conception of responsibility in the given situation, the greater chance that $\mathrm{s} /$ he will make a decision which is an appropriate response to the situation ..." [103] (p. 31).

When relating the presented survey's results and proposed model to others, while considering all research goals formulated in this article, four studies should be highlighted:

Study 1. Connected to the achievement of research Goal Number 1 (to disclose the components that have to be respected in the decision process targeting the appropriate forming of motivation), a qualitative study of Casey and Sieber could be mentioned. These authors emphasize that the development of human resources/human potential is " ... the prerequisite and beginning of a lasting change: change that begins in the minds of all employees; change that is continuous in terms of adaptation of visions, strategies, production processes and organizational structures; change that leads to sustainability, corporate social responsibility, motivation and engagement ... " [104] (p. 75).

Study 2. The extensive empirical study of Palomino, Medina and Arellano, using a sample of 1271 employees, was based on analysis of the differences in motivators and confirmed the existence of significant differences in the importance given to the motivational and organizational values among the four generations of employees [105]. This opinion supports the premise of the importance of time when examining and deciding on how to motivate employees and managers appropriately and effectively. Concurrently, the mentioned analysis supports the current article's goal of setting the principles and mechanisms that must be kept in the process of motivational decision making (Goal Number 2).

Study 3 and Study 4. Connecting to the search for the affect-capable factors that influence and decide the resultant level of perceived motivation (research Goal Number 3), the study of Cewińska and Striker and that of Kulkarni can be highlighted. Cewińska and Striker's study used a sample of 1002 managers and examined the targeting of managerial decision making. Most subjects $(78 \%)$ declared that they had an exclusive or big influence on managerial decisions related to subordinate employees, particularly with regard to appraisal (88\%), hiring (84\%), training $(81 \%)$, dismissal $(76 \%)$, promotion (75\%), and remuneration (66\%) [106] (pp. 51-52). These results emphasize the real ties between the managerial decisions and processes of HPD\&M and justify the philosophy of the currently proposed model. Kulkarni [65], in a more concrete perspective of searching for factors capable to impact motivation, used the focus group method on a sample of 10 targeted companies. The author examined the relationship between sustainable and effective leadership and intrinsic motivation. The study points out that " ... employees are more likely to be intrinsically motivated if the company has a compelling vision, clear objectives, and a supportive culture. It is also important that employees prefer using the skills needed to perform their duties and have their values aligned with core values of the company ..." (p. 86). Naturally, " ... the departmental objectives should be in line with those of the corporation as a whole ... " [107] (p. 39). Based on this, " ... effective leaders strive to create an environment that is intrinsically motivating ..." [36] (p. 77). These findings also support the results of theoretical and practical research performed by the current article's authors, especially the 
premise of the connected and harmonized effect of HPD\&M processes on building sustainable and responsible motivation.

A more complex perspective shows an essence of the presented model is aptly captured in the following idea: "Managers have to be aware that one of the most important stakeholders the organization has is the employee ..." [7]. Additionally, strategic decisions about the motivation of this stakeholder have to be always thoroughly prepared and reasoned.

\section{Conclusions}

Based on the above-mentioned discussion, sustainably responsible motivation, viewed from the perspective of responsible decision making, performed in the processes of human potential development and motivation, is a basis for both current and future growth. Opinions and decisions recommended in this article can be perceived as further elements that promote sustainability-when employees and managers think about their motivation and forms of its improvement by the employer, they perceive their motivation over the long term and are willing to shape it permanently, thus sustainably.

Taking the viewpoint of implications and limitations of the presented ideas and the proposed model, the model is based on sociological questioning performed in three countries of Central and North-Eastern Europe. Due to this, it can be valid just for populations similar or consistent with such demographic and cultural features. Additionally, the potential application of this model in terms of practice assumes, first and foremost, the support from top management, such as the chief-executive of organization (CEO) and senior-management. It is also necessary to accept the fact that the quality of decision making is not only important in other business/organizational processes (marketing, finance, etcetera.), but that it acquires extraordinary importance in the processes of motivating individuals and groups. The prerequisite for achieving sustainably responsible motivation is the high professionalism of all other managers and perfect procedural and facilitation services by the HR department.

Supplementary Materials: The following files are available online at http:/ / www.mdpi.com/2071-1050/10/10/ 3393/s1.

Author Contributions: M.B. built the conceptual framework and coordinated the research; R.B., I.F. and R.A. performed the questionnaire survey; K.P. analyzed the data and commented all results; M.B. and R.B. wrote the paper.

Funding: This research was funded by the Ministry of Education of Slovak Republic-Project KEGA No. 041ŽU-4/2017 Experimental Mathematics Accessible for All.

Conflicts of Interest: The authors declare no conflict of interest.

\section{References}

1. Hohnen, P. Corporate Social Responsibility. An Implementation Guide for Business; International Institute for Sustainable Development: Winnipeg, MB, Canada, 2007; ISBN 978-1-895536-97-3.

2. World Commission on Environment and Development. Our Common Future; Oxford University Press: Oxford, UK, 1987.

3. Jereb, B.; Kukovič, D.; Cvahte, T. Lifelong learning program in university/industry partnership project Tempus RECOAUD: Training of eco-management and climate change adaptation. In Proceedings of the International Scientific Conference Human Potential Development 2017, Szczecin, Poland, 7-9 June 2016; University of Szczecin: Szczecin, Poland, 2017; pp. 101-111, ISBN 978-83-7518-782-3.

4. Maletic, M.; Maletic, D.; Dahlgaard, J.; Dahlgaard, S.M.; Gomiscek, B. Do corporate sustainability practices enhance organizational economic performance? Int. J. Qual. Serv. Sci. 2015, 7, 184-200. [CrossRef]

5. Vojáček, O.; Louda, J. Economic value of ecosystem services in the Eastern Ore Mountains. Econ. Manag. (EEM) 2017, 20, 4-18. [CrossRef]

6. Zhang, D.; Ma, Q.; Morse, S. Motives for Corporate Social Responsibility in Chinese Food Companies. Sustainability 2018, 10, 117. [CrossRef] 
7. Sánchez-Hernández, M.I.; Gallardo-Vázquez, D.; Barcik, A.; Dziwiński, P. The effect of the internal side of social responsibility on firm competitive success in the business services industry. Sustainability 2016, 8, 179. [CrossRef]

8. Son, H.; Lee, J.; Chung, Y. Value creation mechanism of social enterprises in manufacturing industry: Empirical evidence from Korea. Sustainability 2018, 10, 46. [CrossRef]

9. Dreyer, M.; Chefneux, L.; Goldberg, A.; von Heimburg, J.; Patrignani, N.; Schofield, M.; Shilling, C. Responsible innovation: A complementary view from industry with proposals for bridging different perspectives. Sustainability 2017, 9, 1719. [CrossRef]

10. Stýblo, J. Innovation behaviour and creativity as the way to organizational effectivity. In Proceedings of the International Scientific Conference Human Potential Development 2017, Szczecin, Poland, 7-9 June 2016; University of Szczecin: Szczecin, Poland, 2017; pp. 258-265, ISBN 978-83-7518-782-3.

11. López, M.V.; Garcia, A.; Rodriguez, L. Sustainable development and corporate performance: A study based on the Dow Jones Sustainability Index. J. Bus. Ethics 2007, 75, 285-300. [CrossRef]

12. Ansari, W.E.; Stibbe, A. Public health and the environment: What skills for sustainability literacy-And why? Sustainability 2009, 1, 425-440. [CrossRef]

13. Marková, V.; Lesníková, P.; Kaščáková, A.; Vinczeová, M. The present status of sustainability concept implementation by business in selected industries in the Slovak Republic. Econ. Manag. (EEM) 2017, 20, 101-117. [CrossRef]

14. Palacios-Agundez, I.; Onaindia, M.; Barragueta, P.; Madariaga, I. Provisioning ecosystem services supply and demand: The role of landscape management to reinforce supply and promote synergies with other ecosystem services. Land Use Policy 2015, 47, 145-155. [CrossRef]

15. Tovey, H. Sustainability: A platform for debate. Sustainability 2009, 1, 14-18. [CrossRef]

16. Boudreau, J.W.; Ramstad, P.M. Beyond HR: The New Science of Human Capital; Harvard Business School Press: Boston, MA, USA, 2007; ISBN 978-1422104156.

17. Christina, S.; Dainty, A.; Daniels, K.; Tregaskis, O.; Waterson, P. Shut the fridge door! HRM alignment, job redesign and energy performance. Hum. Resour. Manag. J. 2017, 27, 382-402. [CrossRef]

18. Blašková, M.; Blaško, R. Sustainable development of rural tourism through relations between customers' and employees' motivation. Manag. Theory Stud. Rural Bus. Infrastruct. Dev. 2008, 4, 19-28.

19. Ehnert, I. Sustainable Human Resource Management-A Conceptual and Exploratory Analysis from a Paradox Perspective; Physica-Verlag: Berlin/Heidelberg, Germany, 2009; ISBN 978-3-7908-2187-1.

20. Beer, M.; Boselie, P.; Brewster, C. Back to the future: Implications for the field of HRM of the multistakeholder perspective proposed 30 years ago. Hum. Resour. Manag. 2015, 54, 427-438. [CrossRef]

21. Maslow, A.H. A theory of human motivation. Psychol. Rev. 1943, 50, 370-396. [CrossRef]

22. Deci, E.L.; Koestner, R.; Ryan, R.M. A meta-analytic review of experiments examining the effects of extrinsic rewards on intrinsic motivation. Psychol. Bull. 1999, 125, 627-668. [CrossRef] [PubMed]

23. Rosak-Szyrocka, J. Employee's motivation at hospitals as a factor of the organization success. Hum. Resour. Manag. Ergon. 2014, 8, 102-111. Available online: http:/ / frcatel.fri.uniza.sk/hrme/archi-sk.html (accessed on 10 January 2018).

24. James, L.R.; Rentsch, J.R. Justify to explain the reasons why: A conditional reasoning approach to understanding motivated behavior. In Personality and Organizations; Schneider, B., Smith, D.B., Eds.; Psychology Press: New York, NY, USA, 2012; pp. 223-250, ISBN 978-0-415-65078-6.

25. Hill, T. How to Keep Your Best People: Develop a "Level 4" Mindset in Your Line Managers. Dev. Learn. Organ. 2016, 30, 3-6. [CrossRef]

26. Armstrong, M. Handbook of Human Resource Practice, 8th ed.; Kogan Page: London, UK, 2001.

27. Armstrong, M. Handbook of Human Resource Practice, 10th ed.; Kogan Page: London, UK, 2009.

28. Koubek, J. Personnel Work in Small and Medium-Sized Companies, 3rd ed.; Grada: Prague, Czech Republic, 2011.

29. Blašková, M. Human Potential Management and Development. Applying the Motivational Accent in Processes of Human Potential Development; EDIS: Žilina, Slovak Republic, 2003; ISBN 80-8070-034-6.

30. Blašková, M.; Stachová, K.; Poláčková, K.; Stacho, Z.; Blaško, R. Motivation: Motivational Spirals and Decision Making; Oficyna Wydawnicza Stowarzyszenia Menedżerów Jakości i Produkcji: Czestochowa, Poland, 2018; ISBN 978-83-63978-70-9. 
31. Olejniczak, K.; Majchrzak-Lepczyk, J. Social responsibility as the factor of competitive advantage of public entities. Hum. Resour. Manag. Ergon. 2014, 8, 74-87. Available online: http://frcatel.fri.uniza.sk/hrme/archisk.html (accessed on 12 January 2018).

32. Wang, Y.; Liu, D.; Ruhe, G. Formal description of the cognitive process of decision making. In Proceedings of the Third IEEE International Conference on Cognitive Informatics, Victoria, BC, Canada, 17 August 2004; pp. 124-130.

33. Tepper, B.B. Managerial Knowledge and Skills; Grada Publishing: Prague, Czech Republic, 1996; ISBN 80-7169-347-2.

34. Davies, J.L.; Turnbull, O.H. Affective bias in complex decision making: Modulating sensitivity to aversive feedback. Motiv. Emot. 2011, 2, 235-248. [CrossRef]

35. Bono, E. Creative Solutions: How Creativity Can Help with Decision Making and Analysis. 12 December 2008. Available online: www.thinkingmanagers.com/management/creative-solutions (accessed on 19 August 2018).

36. Drucker, P. The Effective Decision. Harvard Business Review on Decision Making; HBS Publishing Corporation: Boston, MA, USA, 2001; pp. 1-21.

37. Osinovskaya, I.V.; Lenkova, O.V. The technological development of managerial decisions on the productive capacity of oil producing industrial building structures. Int. Bus. Manag. 2015, 9, 164-168.

38. Knowles, T.W. Management Science. Building and Using Models; Richard D. Irwin, Inc.: Homewood, IL, USA, 1989; ISBN 0-256-05682-X.

39. Humphrey, J.A.; Pearce, M.R.; Burgoyne, D.G.; Erskin, J.A.; Mimick, R.H. Introduction to Business Decision Making, 3rd ed.; Scarborough: Nelson, BC, Canada, 1988; ISBN 0-17-603449-8.

40. Dalal, R.S.; Brooks, M.E. Individual Differences in Decision making Skill and Style. In Judgment and Decision Making at Work; Highhouse, S., Dalal, R.S., Salas, E., Eds.; Routledge: New York, NY, USA, 2014; pp. 80-101, ISBN 978-1-138-80171-4.

41. Simon, H.A. The Sciences of the Artificial, 3rd ed.; MIT Press: Cambridge, MA, USA, 1996.

42. Blašková, M.; Blaško, R. Intentional versus unintentional decision making in motivating. In Proceedings of the Monograph from International Conference Toyotarity in the European Culture, Ustron Jaszowiec, Poland, 4-6 December 2015; pp. 49-62, ISBN 978-83-63978-25-9.

43. Nyambuu, U.; Tapiero, C.S. Globalization, Gating, and Risk Finance; John Wiley \& Sons, Ltd.: Hoboken, NJ, USA, 2018; ISBN 978-11-19252-68-9.

44. Banerjee, S.; Gücbilmez, I.U.; Pawlina, G. A Theory of Loan Commitments Based on the Borrower's Investment Incentives; Lancaster University Management School: Lancaster, UK, 2009. Available online: http:/ /www. realoptions.org/papers2009/41.pdf (accessed on 2 February 2018).

45. Van der Westhuizen, B. Antecedents, outcomes and personal factor used by sales managers to assess the performance of salespeople. In Proceedings of the 1993 Academy of Marketing Science (AMS) Annual Conference, Miami Beach, FL, USA, 26-29 May 1993; Levy, M., Grewal, D., Eds.; Springer Science + B.M.: Heidelberg, Germany, 2015; pp. 317-321, ISBN 978-3-319-13158-0.

46. Sokół, A. Diagnosis of intellectual capital in macroeconomic terms on the example of Szczecin and opportunities for development of creative sector. Hum. Resour. Manag. Ergon. 2017, 11, 59-75. Available online: http:/ / frcatel.fri.uniza.sk/hrme/archi-sk.html (accessed on 28 January 2018).

47. Rosak-Szyrocka, J. Human resource management in Kaizen aspect. Hum. Resour. Manag. Ergon. 2017, 11, 80-92. Available online: http:/ / frcatel.fri.uniza.sk/hrme/archi-sk.html (accessed on 18 February 2018).

48. Carnall, C.A. Managing Change in Organizations; Prentice Hall: London, UK, 1990; ISBN 0-13-551862-8.

49. Armstrong, M. A Handbook of Employee Reward Management and Practice, 2nd ed.; Kogan Page: London, UK, 2007.

50. Driskel, T.; Driskell, J.E.; Salas, E. Stress, performance and decision making in organizations. In Judgment and Decision Making at Work; Highhouse, S., Dalal, R.S., Salas, E., Eds.; Routledge: New York, NY, USA, 2014; pp. 251-276, ISBN 978-1-138-80171-4.

51. Tyson, S.; Jackson, T. Organizational Behavior; Grada: Prague, Czech Republic, 1997.

52. Kachaňáková, A. Human Resources Management; Sprint, vfra: Bratislava, Slovak Republic, 2007.

53. Frankel, E.G. Quality decision management-The heart of effective futures-oriented management. In Topics in Safety, Risk, Reliability and Quality; Springer Science + Business Media B. V.: Berlin, Germany, 2008; Volume 14, ISBN 978-90-481-8048-6.

54. Blašková, M.; Poláčková, K. Managerial decision making in motivate as support for safe and ethical behaviour at public universities. Public Secur. Public Order 2018, 20, 32-42. 
55. Albers, H.H. Principles of Management. A Modern Approach, 3rd ed.; John Wiley \& Sons, Inc.: New York, NY, USA, 1969.

56. Blašková, M. Human Potential Development. Motivating, Communicating, Harmonizing and Decision Making; EDIS: Žilina, Slovak Republic, 2011; ISBN 978-80-554-0430-1.

57. Barbuto, J.E. Motivation and transactional, charismatic, and transformational leadership. A test of antecedents. J. Leadersh. Organ. Stud. 2005, 11, 26-40. [CrossRef]

58. Barney, J.B.; Wicks, J.; Scharmer, C.O.; Pavlovich, K. Exploring Transcendental Leadership: A Conversation. J. Manag. Spirit. Relig. 2015, 12, 290-304. [CrossRef]

59. Rezaei, G.; Mardani, A.; Senin, A.A.; Wong, K.Z.; Sadeghi, L.; Najmi, M.; Shaharoun, A.M. Relationship between culture of excellence and organizational performance in Iranian manufacturing companies. Total Qual. Manag. Bus. Excel. 2016, 27, 94-115. [CrossRef]

60. Stacho, Z.; Urbancová, H.; Stachová, K. Organizational arrangement of human resources management in organizations operating in Slovakia and Czech Republic. Acta Universitatis Agriculturae et Silviculturae Mendelianae Brunensis 2013, 61, 2787-2799. [CrossRef]

61. Brooks, I. Organisational Behaviour; Pearson Education: London, UK, 2003.

62. Blaško, R. Teaching mathematics at university and removing mathematics anxiety: Theoretical and empirical examination. In Proceedings of the International Scientific Conference Human Potential Development 2017, Prague, Czech Republic, 6-8 June 2017; Institute for Public Administration Prague: Nové Město, Czechia; pp. 7-17, ISBN 978-80-86976-41-9.

63. Amabile, T.M.; Kramer, S.J. What really motivates workers. Harv. Bus. Rev. 2010, January-February, 44-45. Available online: http:/ /hbr.org/2010/01/the-hbr-list-breakthrough-ideas-for-2010/ar/1 (accessed on 9 March 2016).

64. Figurska, I. Dignity management as a new approach to human resources management. Hum. Resour. Manag. Ergon. 2017, 11, 23-37. Available online: http:/ / frcatel.fri.uniza.sk/hrme/archi-sk.html (accessed on 24 January 2018).

65. Kulkarni, S.M. A review on intrinsic motivation: A key to sustainable and effective leadership. Rev. Integr. Bus. Econ. Res. 2015, 4, 74-88.

66. Higgins, E.T.; Cornwell, J.F.M.; Franks, B. "Happiness" and "the good life" as motives working together effectively. Adv. Motiv. Sci. 2014, 1, 135-179. [CrossRef]

67. Sheldon, K.M.; Hilper, J.C. The balanced measure of psychological needs (BMPN) scale: An alternative domain general measure of need satisfaction. Motiv. Emot. 2012, 36, 439-451. [CrossRef]

68. Arditi, D.; Tokdemir, O.B.; Suh, K. Effect of learning on line-of-balance scheduling. Int. J. Proj. Manag. 2001, 19, 265-277. [CrossRef]

69. Carmeli, A.; Brueller, D.; Dutton, J.E. Learning Behaviours in the Workplace: The Role of High-quality Interpersonal Relationships and Psychological Safety. Syst. Res. Behav. Sci. 2008, 26, 81-98. [CrossRef]

70. Kvaløy, O.; Schöttner, A. Incentives to motivate. J. Econ. Behav. Organ. 2015, 116, 26-42. [CrossRef]

71. Arredondo, F. Case method and transcendent motivations. Int. J. Case Method Res. Appl. 2006, XVIII, $22-28$.

72. Yeager, D.S.; Henderson, M.D.; D’Mello, S.; Paunesku, D.; Walton, G.M.; Spitzer, B.J.; Duckworth, A.L. Boring but important: A self-transcendent purpose for learning fosters academic self-regulation. J. Pers. Soc. Psychol. 2014, 107, 559-580. [CrossRef] [PubMed]

73. Maslow, A.H. Toward a Psychology of Being, 3rd ed.; Wiley: New York, NY, USA, 1998; ISBN 978-0-471-29309-5.

74. Boudreau, J.W.; Ramstad, P.M. Talentship, talent segmentation, and sustainability: A new HR decision science paradigm for a new strategy definition. Hum. Resour. Manag. 2005, 44, 129-136. [CrossRef]

75. Misra, K.B. Sustainability and pathways for implementation. In Handbook of Performability Engineering; Misra, K.B., Ed.; Springer: London, UK, 2008; pp. 857-874, ISBN 978-1-84800-130-5.

76. Berelson, B.; Steiner, G.A. Human Behavior: An Inventory of Scientific Findings; Harcourt, Brace \& World: New York, NY, USA, 1964.

77. Decker, L. Motivation. Biological, Psychological, and Environmental, 4th ed.; Routledge: New York, NY, USA, 2016.

78. Reeve, J. Understanding Motivation and Emotion, 5th ed.; John Wiley \& Sons: Hoboken, NJ, USA, 2009.

79. Milkovich, G.T.; BoudreauF, J.W. Personnel/Human Resource Management. A Diagnostic Approach, 5th ed.; BPI, Irwin: Homewood, IL, USA, 1988.

80. Heckhausen, J.; Heckhausen, H. Motivation und handeln: Einführung und überblick; Springer: Berlin/Heidelberg, Germany, 2006; ISBN 978-3-540-29975-2. 
81. Stombach, T.; Strang, S.; Partk, S.Q.; Kenning, P. Common and distinctive approaches to motivation in different disciplines. In Progress in Brain Research, 229: Motivation-Theory, Neurobiology and Applications; Studer, B., Knecht, S., Eds.; Elsevier: Amsterdam, The Netherlands, 2016; pp. 3-23, ISBN 97-0-044-63701-7.

82. Maslow, A.H. Motivation and Personality, 3rd ed.; Pearson Education: Delhi, India, 1987; ISBN 978-0060419875.

83. Kanfer, R.; Chen, G. Motivation in organizational behavior: History, advances and prospects. Organ. Behav. Hum. Decis. Process. 2016, 136, 6-19. [CrossRef]

84. Blašková, M. Attributes of decision making in motivating employees. Hum. Resour. Manag. Ergon. 2016, 10, 23-37. Available online: http:/ / frcatel.fri.uniza.sk/hrme/archi-sk.html (accessed on 5 February 2018).

85. Blašková, M.; Bízik, M.; Jankal, R. Model of decision making in motivating employees and managers. Eng. Econ. 2015, 26, 517-529. [CrossRef]

86. Roets, A.; Van Hiel, A.; Kruglanski, A.W. When motivation backfires: Optimal levels of motivation as a function of cognitive capacity in information relevance perception and social judgment. Motiv. Emot. 2013, 37, 261-273. [CrossRef]

87. Chen, G.; Kanfer, R. Toward a systems theory of motivated behavior. Res. Organ. Behav. 2006, 27, $223-267$. [CrossRef]

88. Drucker, P. Effective Manager, 2nd ed.; Management Press: Prague, Czech Republic, 1992; ISBN 80-85603-02-0.

89. Matuska, E. Human Resources Management in a Modern Company; Higher School of Administration and Business of E. Kwiatkowski: Gdynia, Poland, 2014; ISBN 978-83-64505-45-7.

90. Mathe, H.; Pavie, X.; O'Keeffe, M. Valuing People to Create Value. An Innovative Approach to Leveraging Motivation at Work; World Scientific Publishing Co. Pte. Ltd.: Singapore, 2012; ISBN 13-978-981-4365-06-2.

91. Aldag, R.J.; Kuzuhara, L.W. Creating High Performance Teams; Routledge, Taylor \& Francis Group: New York, NY, USA; ISBN 978-0-415-53491-8.

92. Finke, I.; Will, M. Motivation for knowledge management. In Knowledge Management, 2nd ed.; Mertins, K., Heisig, P., Vorbeck, J., Eds.; Springer-Verlag: Berlin/Heidelberg, Germany, 2003; pp. 66-91.

93. Gagné, M.; Deci, E.L. The history of self-determination theory in psychology and management. In The Oxford Handbook of Work Engagement, Motivation, and Self-Determination Theory; Gagne, M., Ed.; Oxford University Press: Oxford, UK, 2014. [CrossRef]

94. Meyer, J.P.; Gagné, M. Employee engagement form a self-determination theory perspective. Ind. Organ. Psychol. 2008, 1, 60-62. [CrossRef]

95. Blašková, M.; Hitka, M.; Blaško, R.; Borkowski, S.; Rosak, J.; Križanová, A.; Farkašová, V. Management and Development of High-Qualified Human Potential; Technical University: Zvolen, Slovakia, 2006; ISBN 80-228-1701-5.

96. Index Mundi-Poland \& Lithuania. Available online: https://www.indexmundi.com/factbook/compare/ poland.lithuania (accessed on 21 June 2018).

97. Index Mundi-Slovakia \& Lithuania. Available online: https:/ /www.indexmundi.com/factbook/compare/ poland.lithuania (accessed on 21 June 2018).

98. Country Economy. Available online: https://www.indexmundi.com/factbook/compare/poland.lithuania (accessed on 21 June 2018).

99. Raosoft. Software for Statistical Calculation. Available online: www.raosoft (accessed on 18 August 2018).

100. Lamoš, F.; Potocký, R. Probability and Mathematical Statistics. Statistical Analyses; Alfa: Bratislava, Slovakia, 1989; ISBN 80-05-00115-0.

101. Likeš, J.; Machek, J. Mathematical Statistics; SNTL: Prague, Czech Republic, 1983; ISBN 04-008-83.

102. Zvára, K.; Štěpán, J. Probability and Mathematical Statistics; Charles University: Prague, Czech Republic, 1997; ISBN 80-85863-24-3.

103. Zsolnai, L. Responsible decision making. In Praxiology: The International Annual of Practical Philosophy and Methodology; Translation Publishers: Moncton, NB, Canada, 2008; Volume 16, ISBN 978-1-4128-0818-7.

104. Casey, D.; Sieber, S. Employees, sustainability and motivation: Increasing employee engagement by addressing sustainability and corporate social responsibility. Res. Hosp. Manag. 2016, 6, 69-76. [CrossRef]

105. Palomino, J.A.H.; Medina, J.J.E.; Arellano, M.A. Differences in motivators and values in the work of maquiladora industry employees. Contaduría y Administración 2016, 61, 58-83. [CrossRef] 
106. Cewińska, J.; Striker, M. Lifestyle as a determinant of managerial decisions. Hum. Resour. Manag. Ergon. 2018, 12, 47-58. Available online: http:/ / frcatel.fri.uniza.sk/hrme/archi-sk.html (accessed on 2 July 2018).

107. Bučková, J. Corporate culture as an important factor in the implementary of knowledge management. AD ALTA J. Interdiscip. Res. 2017, 2, 36-39. 